\title{
Development and field testing of a rapid and ultra-stable atmospheric carbon dioxide spectrometer
}

\author{
B. Xiang ${ }^{1}$, D. D. Nelson ${ }^{2}$, J. B. McManus ${ }^{2}$, M. S. Zahniser ${ }^{2}$, R. A. Wehr ${ }^{3}$, and S. C. Wofsy ${ }^{1}$ \\ ${ }^{1}$ School of Engineering and Applied Sciences and Department of Earth and Planetary Sciences, Harvard University, \\ Cambridge, MA 02138, USA \\ ${ }^{2}$ Aerodyne Research, Inc., 45 Manning Road, Billerica, MA 01821-3976, USA \\ ${ }^{3}$ Department of Ecology and Evolutionary Biology, University of Arizona, Tucson, AZ 85721, USA
}

Correspondence to: B. Xiang (bxiang@ seas.harvard.edu)

Received: 10 July 2014 - Published in Atmos. Meas. Tech. Discuss.: 5 August 2014

Revised: 14 November 2014 - Accepted: 20 November 2014 - Published: 15 December 2014

\begin{abstract}
We present field test results for a new spectroscopic instrument to measure atmospheric carbon dioxide $\left(\mathrm{CO}_{2}\right)$ with high precision $\left(0.02 \mu \mathrm{mol} \mathrm{mol}^{-1}\right.$, or ppm at $\left.1 \mathrm{~Hz}\right)$ and demonstrate high stability (within $0.1 \mathrm{ppm}$ over more than 8 months), without the need for hourly, daily, or even monthly calibration against high-pressure gas cylinders. The technical novelty of this instrument (ABsolute Carbon dioxide, $\mathrm{ABC}$ ) is the spectral null method using an internal quartz reference cell with known $\mathrm{CO}_{2}$ column density. Compared to a previously described prototype, the field instrument has better stability and benefits from more precise thermal control of the optics and more accurate pressure measurements in the sample cell (at the mTorr level). The instrument has been deployed at a long-term ecological research site (the Harvard Forest, USA), where it has measured for 8 months without on-site calibration and with minimal maintenance, showing drift bounds of less than $0.1 \mathrm{ppm}$. Field measurements agree well with those of a commercially available cavity ring-down $\mathrm{CO}_{2}$ instrument (Picarro G2301) run with a standard calibration protocol. This field test demonstrates that $\mathrm{ABC}$ is capable of performing high-accuracy, unattended, continuous field measurements with minimal use of reference gas cylinders.
\end{abstract}

\section{Introduction}

Accurate and precise measurement of atmospheric carbon dioxide $\left(\mathrm{CO}_{2}\right)$ is key to monitoring and understanding anthropogenic impacts on atmospheric radiative forcing and climate. To that end, various $\mathrm{CO}_{2}$ instruments have been developed, using techniques such as tunable infrared laser direct absorption spectroscopy (TILDAS), non-dispersive infrared absorption (NDIR) spectroscopy, integrated cavity output spectroscopy (ICOS), cavity ring-down spectroscopy (CRDS), Fourier transform infrared spectroscopy (FTIR), and photoacoustic detection (Andersen et al., 2010; Baer et al., 2002; Engeln et al., 1998; Esler et al., 2000). Particular designs have targeted specific deployment purposes, such as long-term monitoring at remote sites, fast response eddy covariance measurement, mobile platform (i.e., car, ship, balloon, aircraft) in situ sampling, and atmospheric column concentration measurements. One limitation common to all the $\mathrm{CO}_{2}$ instruments (and other stable gas instruments as well) is instrument response drift at various timescales (e.g., hours to days) and the associated need for use of calibration gases to maintain traceability to world standards. The logistics of tank operations - including filling, shipping, housing, pressure regulating, sampling, calibrating, and inter-comparing are cost- and labor-intensive, especially so for instruments deployed in situ, and variations in the composition of gas delivered to the sensors may limit the accuracy of the measurement.

To address the problems presented by the need for periodic calibrations with gas standards, we developed an instrument called ABsolute Carbon dioxide, or ABC (Xiang et al., 2013). ABC relies on what we call the spectral null method, whereby the sample gas spectrum is divided by the spectrum in an internal, sealed quartz cell with a known $\mathrm{CO}_{2}$ optical depth close to that of the sample. The null method 
improves measurement precision and accuracy by reducing the influence of spectral variations associated with laser operating parameters (e.g., tuning rate, laser line width variation and mode purity), absorption line strength changes (e.g., with temperature), optics temperature variations, and spectral fitting. Previous tests showed the prototype instrument had a 1 -second precision of $0.02 \mu \mathrm{mol} \mathrm{mol}^{-1}$ (ppm) and was stable to within $0.1 \mathrm{ppm}$ over a month of unattended operation without calibration (Xiang et al., 2013).

Here we describe the field tests of a next-generation $A B C$ instrument with improved performance demonstrated over many months of operation. The new instrument uses a different instrument platform equipped with better thermal and vibration control and integrated electronics. The instrument has been deployed to a research forest site to measure abovecanopy $\mathrm{CO}_{2}$ mixing ratios continuously for 8 months. Results from periodic surveillance tank measurements and from ambient sampling comparisons to a calibrated $\mathrm{CO}_{2}$ instrument using CRDS (Picarro G2301) show stability within $0.1 \mathrm{ppm}$ for the entire period. This performance puts the $\mathrm{ABC}$ instrument among the best $\mathrm{CO}_{2}$ instruments currently available. It has great potential to be applied to long-term, remote monitoring networks for continuous unattended measurements, with a much simpler quality assurance process. The quartz reference cells could be calibrated at a central lab and delivered to remote sites to ensure consistent measurement standards. The new platform also has the potential to be adopted for other stable gas measurements and eddy covariance flux sampling.

\section{Experimental details}

We employ a variant of Tunable Infrared Laser Direct Absorption Spectroscopy (TILDAS) that incorporates a spectral null technique, comparing the sample spectra to spectra obtained from a permanently sealed quartz reference cell with known $\mathrm{CO}_{2}$ column density. This facilitates high-accuracy, low-drift measurements of ambient $\mathrm{CO}_{2}$ mixing ratios. Basic details of the instrument design, null method, sealed quartz reference cells, data acquisition, and spectral analysis are described by Xiang et al. (2013). Here we discuss in detail the major improvements of the next-generation $\mathrm{ABC}$ instrument, including a new instrument platform with improved thermal control, accurate sample cell pressure measurement, and better-integrated electronics.

\subsection{Optics platform}

$\mathrm{ABC}$ now uses an instrument platform originally developed for simultaneous detection of multiple species using dual lasers (McManus et al., 2010, 2011; Tuzson et al., 2013). A typical Aerodyne Dual (laser) system has dimensions of $53 \mathrm{~cm} \times 66 \mathrm{~cm} \times 71 \mathrm{~cm}(\mathrm{~W} \times \mathrm{D} \times \mathrm{H})$, weight of $72 \mathrm{~kg}$, and draws electrical power of $500 \mathrm{~W}, 120 / 240 \mathrm{~V}$, and $50 / 60 \mathrm{~Hz}$.

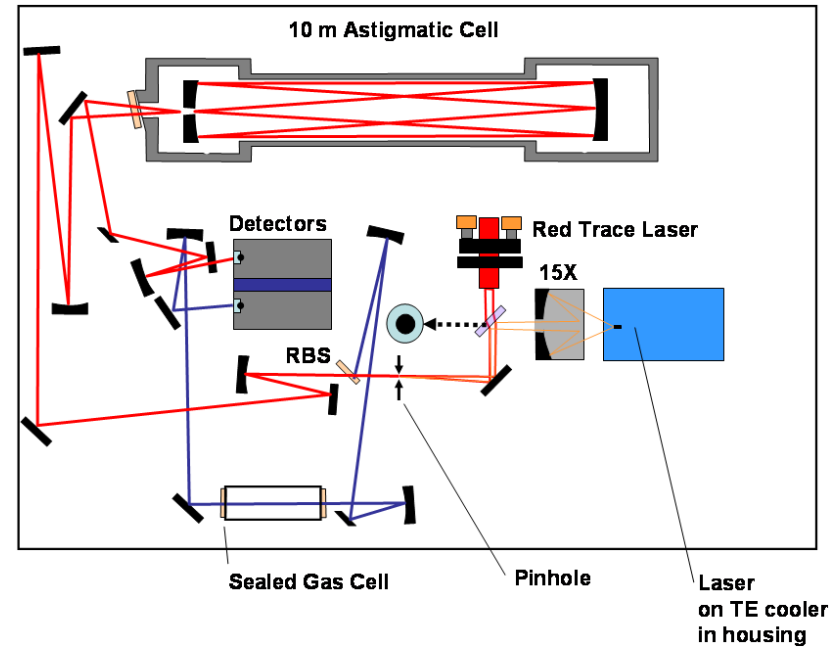

Figure 1. Diagram of the optical module for the ABC platform.

Figure 1 shows the optical module of the current $\mathrm{ABC}$ platform. The design is based on a $43 \mathrm{~cm} \times 64 \mathrm{~cm}$ breadboard.

Here we discuss in detail the special optical features of the current $\mathrm{ABC}$ instrument and contrast them with those of the prior $\mathrm{ABC}$ prototype. We used the same $2.7 \mu \mathrm{m}$ distributed feedback (DFB) diode laser (Nanoplus, Germany), one quartz reference cell, and the AMAC-36 sample cell as in the first prototype instrument and installed two new 5micron $\mathrm{HgCdTe}$ detectors. We selected a different ${ }^{12} \mathrm{C}^{16} \mathrm{O}_{2}$ absorption line $\left(3733.4684 \mathrm{~cm}^{-1}\right)$ than the one used in the first prototype $\left(3735.8480 \mathrm{~cm}^{-1}\right)$. The new line is near another, weaker $\mathrm{CO}_{2}$ absorption line that facilitates laser tuning rate characterization. The diode laser is positioned in a customized thermoelectric cooling (TEC) laser housing (blue in Fig. 1). Its output first gets collected and re-focused by a $15 \times$ reflecting objective mounted on a three-axis translation stage allowing for fine focus adjustments. A pinhole between the first reflecting mirror (black) and the wedged beam splitter (RBS, yellow) serves as a reference point for alignment, with the help from a visible trace laser. The main beam is separated by the RBS into two parts: the transmitted beam (red) goes into the sample multi-pass cell and gets detected by a 5 -micron $\mathrm{HgCdTe}$ detector (Teledyne Judson Technologies, USA; J19TE4:5-3CN-R01M); the front reflected beam (blue) is directed into the quartz reference cell and collected by another detector of the same type as used in the sample beam. We adjusted the sample multi-pass cell absorption path length to $10.20 \pm 0.01 \mathrm{~m}(19.4 \mathrm{~cm}$ mirror separation, 52 passes; McManus et al., 2011) to nearly match the column absorptions in the sample and the reference cells.

The traceable accuracy and the long-term measurement stability performance of $\mathrm{ABC}$ are assured by the permanently sealed quartz reference cell containing known column density of $\mathrm{CO}_{2}$ in dry air. Column density is the product of the $\mathrm{CO}_{2}$ number density and the optical path length of the quartz 
cell $(10 \mathrm{~cm})$. Detailed quartz cell descriptions can be found in Xiang et al. (2013). We fill the quartz cell with $4 \% \mathrm{CO}_{2}$ (in volume, from a pure $\mathrm{CO}_{2}$ tank source) in a total of 5 Torr $(0.7 \mathrm{kPa})$ dry, $\mathrm{CO}_{2}$-free air, in order to obtain the equivalent $\mathrm{CO}_{2}$ mixing ratio in the quartz cell close to the ambient level (the ABC sample cell has an optical path length about 100 times that of the quartz cell). The cell has been pumped before the filling to avoid internal water desorption and sealed by a glass-blower after the filling. The equivalent $\mathrm{CO}_{2}$ mixing ratio in the sealed quartz cell (or the "null point"), at the fixed position inside the current $\mathrm{ABC}$ platform, has been calibrated to be $385.20 \pm 0.02 \mathrm{ppm}$ using reference gas cylinders traceable to the WMO standards (Tans et al., 2009) in the laboratory. Repeated quartz cell reposition tests under laboratory and field transport conditions were performed, and no $\mathrm{CO}_{2}$ measurement shift outside $0.1 \mathrm{ppm}$ range was observed.

\subsection{Pressure measurement}

For $\mathrm{ABC}$ to obtain $0.1 \mathrm{ppm}$ long-term measurement stability, the pressure sensor measurement must be stable to within 1 part in $4000(0.25 \%)$, which is about $1 \mathrm{mTorr}(\sim 0.1 \mathrm{~Pa})$ at the sample cell pressure of about 5 Torr $(\sim 660 \mathrm{~Pa})$. We tested the long-term zero- and span- drift of three commercial sensors: MKS 626B, MKS 627D and MKS 722A (MKS Instruments Inc., USA). These sensors all operate up to 10 Torr with similar specified accuracies $(0.15,0.12$, and $0.5 \%$ of the reading, respectively), but they differ in size, settings, and price. During the test, all three sensors were connected to the ABC sample cell with switch valve controls. The MKS $627 \mathrm{D}$ is temperature self-controlled (the temperature dependence of its zero reading after control is $20 \mathrm{ppm}$ full span (F.S.) $\mathrm{K}^{-1}$ according to the specification) and was therefore placed outside the temperature-controlled $\mathrm{ABC}$ optics box. The other two sensors have greater zero-reading temperature dependencies (50 ppm F.S. $\mathrm{K}^{-1}$ for the $626 \mathrm{~B}$ and $80 \mathrm{ppm}$ F.S. $\mathrm{K}^{-1}$ for the $722 \mathrm{~A}$ according to the specification) and so were placed inside the optics box. The ABC sample cell was also connected to a HOVAC DRI-2 pump system with valve control to serve as the "true" zero pressure. This system combined a molecular drag pump and a diaphragm pump and was capable of pumping the system down to $10^{-5}$ Torr $\left(10^{-3} \mathrm{~Pa}\right)$, which is 2 orders of magnitude smaller than our pressure accuracy requirement. The sample cell was switched to HOVAC pumping periodically for the pressure sensor zero test.

We examined the pressure sensor zero drift periodically over 3 months (Fig. 2). Intensive zero pressure measurements (hourly) were made in the beginning, and the frequency was gradually reduced (from every $3 \mathrm{~h}$ to twice every day) towards the end of the test period. Data gaps in Fig. 2 are due to other $\mathrm{ABC}$ stability tests, but the vacuum system setup was not changed during those periods. Results show that the MKS 626B had the least zero-reading drift, less than $1 \mathrm{mTorr}$ over the 3-month period (excluding the initial sensor stabilizing and vacuum system out-gassing period). The MKS 722A

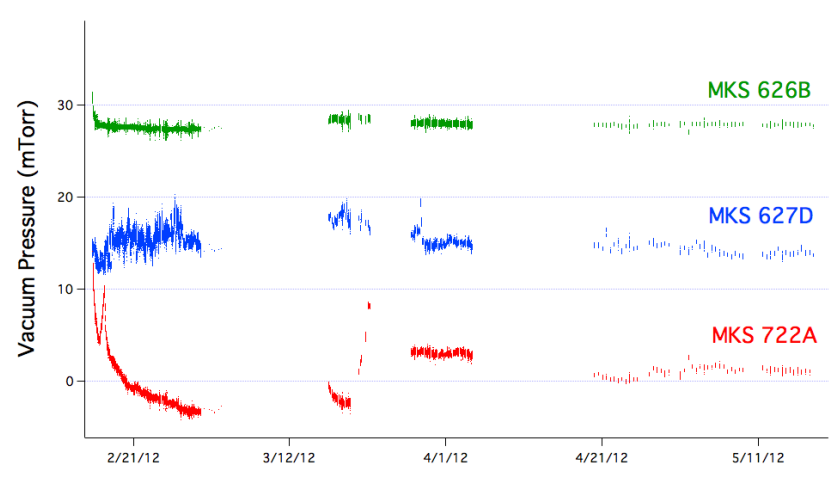

Figure 2. Measurements of the zero drift for three commercial pressure sensors over 3 months. Measurement frequency changes from hourly in the beginning to 3 hourly and twice daily at later times. Data gaps are due to other stability tests and the vacuum connection remains the same throughout this period.

had the worst performance, with drifts and sporadic changes up to 10 mTorr. These big changes did not appear in the measurements of the other two sensors and were likely associated with the turning on of the $722 \mathrm{~A}$ sensor. This test was repeated on the MKS 626B later for an even longer time (6 months) and again its zero-drift was no more than 1 mTorr.

In addition to zero drift, we examined the span drift of all three commercial pressure sensors around the working pressure of the sample cell. The cell pressure was controlled by a flow controller (500 sccm range, MKS 0248A-00500SV) and varied within 0.1 Torr around 5 Torr during normal operation. Due to the lack of absolute pressure references in this range, we chose to check for span drift by comparing these three MKS sensors in pairs. Over a 1-month test period (15 February-17 March 2013), the most stable pressure reading comparison was between the MKS 627D and the MKS $626 \mathrm{~B}$. The ratio of their pressure readings $\left(P_{627 \mathrm{D}} / P_{626 \mathrm{~B}}\right.$, zero-drift corrected) was $1.0023 \pm 0.0001$ (1 standard deviation), suggesting very small span drift ( 0.01 percent) between the two sensors around the cell pressure. Based on these zeroand span-drift tests, we choose to install the MKS 626B in the $\mathrm{ABC}$ system, to measure the sample cell pressure with mTorr $(0.25 \%$ o ) accuracy.

\subsection{Temperature control}

Temperature influences the instrument's stability through a variety of mechanisms including the phase motion of optical fringes, changes in laser tuning, and temperature dependence of the $\mathrm{CO}_{2}$ absorption line strength combined with temperature measurement errors. In developing the first $A B C$ prototype, we improved the temperature stability of the optics by adopting a re-circulating liquid coolant scheme (Xiang et al., 2013). A commercial thermoelectric chiller, ThermoCube 300 (Solid State Cooling Inc, USA), was used in that setup. More recently a new chiller permitting remote control of its set point with $\mathrm{mK}$ resolution was developed 


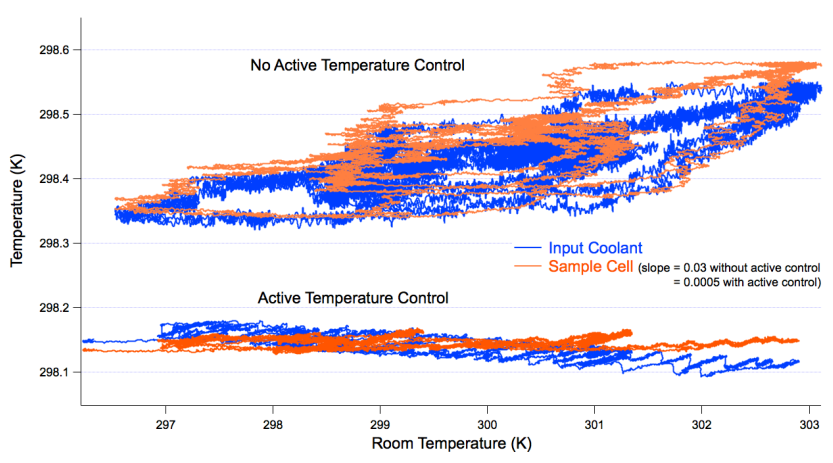

Figure 3. Temperature control effects on the ABC optics with and without a newly developed active control loop.

(Oasis 3, Solid State Cooling Inc, USA). We have been able to couple $\mathrm{ABC}$ and the Oasis 3 to realize active temperature control of a selected point in the optics enclosure, further improving instrument stability.

Usually, re-circulating chillers regulate temperature by attempting to maintain the fluid in the chiller at a fixed, manually selected set point. There are two problems with this approach: (1) some thermal loss/gain from/to the fluid en route to/from $\mathrm{ABC}$ is inevitable, so that if the fluid temperature in the chiller is stable, then the fluid temperature inside $A B C$ will vary with the room temperature, and (2) the temperature of the fluid output by the chiller is potentially dependent on the room temperature as well. To help relieve these problems, we built a temperature control feedback loop between ABC and the Oasis 3 whereby the Oasis 3 set point is adjusted (via USB with $1 \mathrm{mK}$ resolution) in order to maintain a stable temperature at a fixed location inside the optics box.

The benefit of the water temperature feedback control loop is illustrated in Fig. 3. Without the active control loop (top panel), the measured temperatures of the sample cell inside the optics box (orange) and of the coolant input to the optics box (blue) have a 1-part-in-30 dependence on the ambient temperature variation. With the active control loop using the sample cell as the sensing point (bottom panel), the coolant temperature is continuously adjusted by TDLWintel (the ABC control software), via the Oasis 3, such that the sample cell temperature stayed constant to within about $30 \mathrm{mK}$ around 298.15 over $7 \mathrm{~K}$ changes in the ambient temperature (i.e., temperature of the control point varies by less than 1 part in 200 of the ambient temperature changes). We also improved the thermal stability of the separate electronics box through insulation and closed-loop ventilation with a heat exchanger and a separate chiller.

\section{Instrument field performance}

\subsection{Harvard Forest deployment}

We field-tested the ABC instrument at the Harvard Forest Environmental Measurements Site (HF-EMS) from June 2013 until February 2014 - a test period of 8 months. HF-EMS is a long-term ecological research site located in Petersham, Massachusetts, USA. The site is heavily forested, dominated by red oak and red maple. It has been described in detail elsewhere (Wofsy et al., 1993; Goulden et al., 1996; Urbanski et al., 2007). ABC measures from the eddy flux tower $(30 \mathrm{~m}$ tall), along with two other $\mathrm{CO}_{2}$ instruments: an Aerodyne $\mathrm{CO}_{2}$-isotope spectrometer (Wehr et al., 2013) and a Picarro G2301 (Picarro Inc., USA).

$\mathrm{ABC}$ was plumbed in parallel with the Aerodyne $\mathrm{CO}_{2}$ isotope spectrometer. Both instruments received gas from the same valve manifold, with $A B C$ taking about $400 \mathrm{sccm}$ of the total $3500 \mathrm{sccm}$ flow via a tee inserted immediately before the isotopic spectrometer. The manifold sampled the air at the top of the canopy for most of the time, with intermittent sampling of vertical canopy profiles and of the secondary reference gas cylinders for the $\mathrm{CO}_{2}$-isotope spectrometer (also called the working tank pairs: low span between 350 and $360 \mathrm{ppm}$ and high span between 450 and $455 \mathrm{ppm}$ ). We stress that these working tanks were never used to calibrate $A B C$; indeed, $\mathrm{ABC}$ has not been calibrated once since its movement to the Harvard Forest in June 2013. It has been measuring continuously at $1 \mathrm{~Hz}$ without any maintenance, except for occasional site power, purge gas (i.e., $\mathrm{CO}_{2}$ - and $\mathrm{H}_{2} \mathrm{O}$-free gas), and pump failures. The restored performance of $\mathrm{ABC}$ was not affected by power or pump failure. The instrument automatically restarts itself and continues requiring data after power failures. After a pump replacement, the sample flow rate should be checked and maintained the same as before to ensure measurement stability. All of the $\mathrm{ABC} \mathrm{CO}_{2}$ values reported here, including the working tank gas values, come directly from the instrument's real-time measurements.

\subsection{Field performance - stability}

The daily performance and long-term stability of $\mathrm{ABC}$ in the field were evaluated by using the working tank pairs (hourly) as well as five reference tanks (occasionally) as surveillance tanks. Each working tank pair (aluminum cylinders; Airgas Inc., USA) was measured every $1.5 \mathrm{~h}$ and was replaced once the internal pressure dropped below about 500 psi. There are a total of five pairs of working tanks measured over the 8 months. Another five reference tanks (aluminum cylinders; Scott Specialty Gases and Scott-Marrin Inc., USA) were measured three times on site with 5 months apart (dates and values in Table 1). Figure 4a shows ABC's daily mean working tank measurements with error bars indicating the subdaily measurement variation (1 standard deviation). Measurements of five reference tanks are also plotted with longer 
Table 1. Surveillance tank $\mathrm{CO}_{2}$ information and repeated ABC measurements at Harvard Forest in between June 2013 and February 2014. Errors are 1 standard deviation from repeated measurements.

\begin{tabular}{|c|c|c|c|c|c|c|}
\hline & $\begin{array}{l}\text { Licor } \mathrm{CO}_{2}^{\mathrm{a}} \\
(\mathrm{ppm})\end{array}$ & $\begin{array}{l}\delta^{13} \mathrm{C}^{\mathrm{b}} \\
(\% o)\end{array}$ & $\begin{array}{l}\delta^{18} \mathrm{O}^{\mathrm{b}} \\
(\% o)\end{array}$ & $\begin{array}{l}\text { Corrected } \mathrm{CO}_{2} \\
(\mathrm{ppm})^{\mathrm{c}}\end{array}$ & $\begin{array}{l}\mathrm{ABC} \mathrm{CO}_{2} \\
(\mathrm{ppm})\end{array}$ & Measurement date \\
\hline \multicolumn{7}{|c|}{ Aluminum gas cylinders } \\
\hline$\# 1$ & $346.728 \pm 0.011$ & $-48.94 \pm 0.26$ & $+35.57 \pm 0.23$ & 346.6306 & $\begin{array}{l}346.18 \pm 0.03 \\
346.33 \pm 0.01 \\
346.38 \pm 0.01\end{array}$ & $\begin{array}{l}9 \text { Sep } 2013 \\
\text { 30 Jan } 2014 \\
\text { 20 Feb } 2014\end{array}$ \\
\hline$\# 2$ & $377.651 \pm 0.016$ & $-37.12 \pm 0.19$ & $+6.27 \pm 0.13$ & 377.5929 & $\begin{array}{l}377.54 \pm 0.03 \\
377.55 \pm 0.01 \\
377.56 \pm 0.02\end{array}$ & $\begin{array}{l}9 \text { Sep } 2013 \\
\text { 30 Jan } 2014 \\
\text { 20 Feb } 2014\end{array}$ \\
\hline \#3 & $402.937 \pm 0.006$ & $-37.38 \pm 0.15$ & $+6.10 \pm 0.09$ & 402.8743 & $\begin{array}{l}402.82 \pm 0.03 \\
402.79 \pm 0.02 \\
402.78 \pm 0.02\end{array}$ & $\begin{array}{l}9 \text { Sep } 2013 \\
30 \text { Jan } 2014 \\
20 \text { Feb } 2014\end{array}$ \\
\hline$\# 4$ & $422.128 \pm 0.027$ & $-37.52 \pm 0.17$ & $+5.52 \pm 0.12$ & 422.0622 & $\begin{array}{l}422.01 \pm 0.03 \\
421.69 \pm 0.02 \\
421.66 \pm 0.01\end{array}$ & $\begin{array}{l}9 \text { Sep } 2013 \\
\text { 30 Jan } 2014 \\
20 \text { Feb } 2014\end{array}$ \\
\hline \#5 & $457.196 \pm 0.004$ & $-38.04 \pm 0.20$ & $+4.97 \pm 0.13$ & 457.1233 & $\begin{array}{l}456.66 \pm 0.03 \\
456.45 \pm 0.04 \\
456.41 \pm 0.02\end{array}$ & $\begin{array}{l}9 \text { Sep } 2013 \\
30 \text { Jan } 2014 \\
20 \text { Feb } 2014\end{array}$ \\
\hline \multicolumn{7}{|c|}{ Steel gas cylinders ${ }^{\mathrm{d}}$} \\
\hline \#1 & $332.693 \pm 0.016$ & -10.34 & +34.31 & 332.6947 & $\begin{array}{l}332.91 \pm 0.04 \\
332.91 \pm 0.04 \\
332.89 \pm 0.03 \\
332.87 \pm 0.05 \\
332.78 \pm 0.09 \\
332.91 \pm 0.02\end{array}$ & $\begin{array}{l}\text { 19 Jun } 2013 \\
\text { 11 Sep } 2013 \\
22 \text { Oct } 2013 \\
\text { 20 Dec } 2013 \\
\text { 30 Jan } 2014 \\
20 \text { Feb } 2014\end{array}$ \\
\hline \#2 & $431.150 \pm 0.051$ & -15.10 & +30.80 & 431.1392 & $\begin{array}{l}430.65 \pm 0.03 \\
430.55 \pm 0.03 \\
430.51 \pm 0.03 \\
430.29 \pm 0.04 \\
430.21 \pm 0.04 \\
430.35 \pm 0.02\end{array}$ & $\begin{array}{l}19 \text { Jun } 2013 \\
11 \text { Sept } 2013 \\
22 \text { Oct } 2013 \\
20 \text { Dec } 2013 \\
\text { 30 Jan } 2014 \\
\text { 20 Feb } 2014\end{array}$ \\
\hline \#3 & $496.444 \pm 0.060$ & -15.13 & +30.93 & 496.4314 & $\begin{array}{l}495.06 \pm 0.04 \\
495.07 \pm 0.07 \\
494.70 \pm 0.05 \\
494.17 \pm 0.07 \\
493.97 \pm 0.02 \\
494.10 \pm 0.04\end{array}$ & $\begin{array}{l}\text { 19 Jun } 2013 \\
\text { 11 Sep } 2013 \\
22 \text { Oct } 2013 \\
20 \text { Dec } 2013 \\
\text { 30 Jan } 2014 \\
\text { 20 Feb } 2014\end{array}$ \\
\hline
\end{tabular}

\footnotetext{
a The raw values of $\mathrm{CO}_{2}$ mole fractions in tanks were measured by a modified Licor 6251 (Daube et al., 2002) and calibrated against tanks (filled with natural air) traceable to the $\mathrm{WMO}$ total $\mathrm{CO}_{2}$ standards. Measurements were repeated twice for each tank on two different days.

${ }^{\mathrm{b}}$ Isotopic compositions of $\mathrm{CO}_{2}$ in the aluminum surveillance tanks were calibrated by the Aerodyne QCLS_CO $\mathrm{C}_{2}$ isotope instrument, referencing to a standard tank characterized by IRMS at the Stable Isotope Ratio Facility for Environmental Research (SIRFER) at the University of Utah. $\delta^{13} \mathrm{C}$ values are on the VPDB scale $\left(\mathrm{R} 13 \_\mathrm{VPDB}=0.0111797\right) ; \delta^{18} \mathrm{O}$ values are on the VSMOW scale $\left(\mathrm{R} 18 \_\right.$VSMOW $\left.=0.0020052\right)$. Isotopic compositions of $\mathrm{CO}_{2}$ in the steel surveillance tanks were measured directly by IRMS at SIRFER, University of Utah.

${ }^{c}$ The corrected $\mathrm{CO}_{2}$ values were calculated by correcting the tank $\mathrm{CO}_{2}$ isotopic compositions for those in natural air $\left(-10 \%\right.$ for $\delta^{13} \mathrm{C}$ and $40 \%$ for $\delta^{18} \mathrm{O}$ ), and by correcting the Licor responses using mean RMR values (1.00565, 0.33 and 1.345 for 626,636 and 628$)$ from the two Li-6252 instruments studied in Tohjima et al. (2009).

${ }^{\mathrm{d}}$ Repeated ABC measurements of steel surveillance tanks show large variations associated with environment temperature. See discussion in Sect. 3.4 for details.
} 


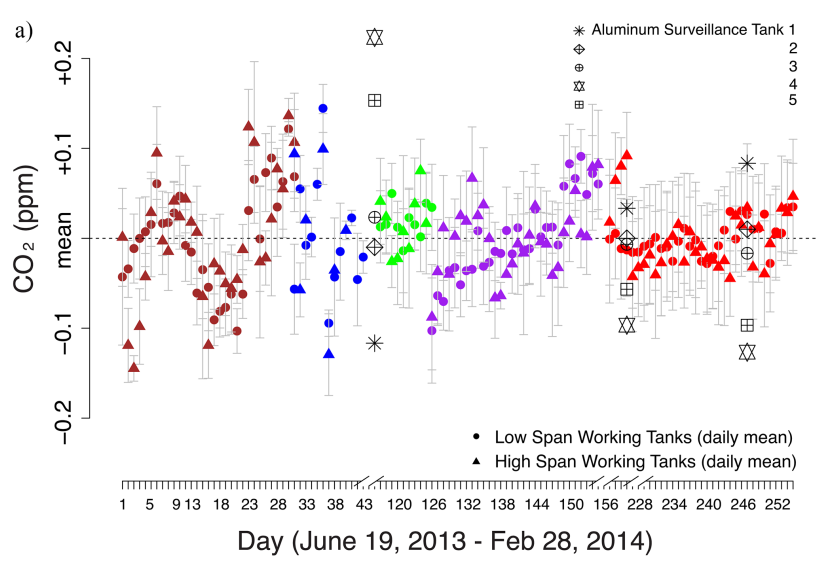

b)
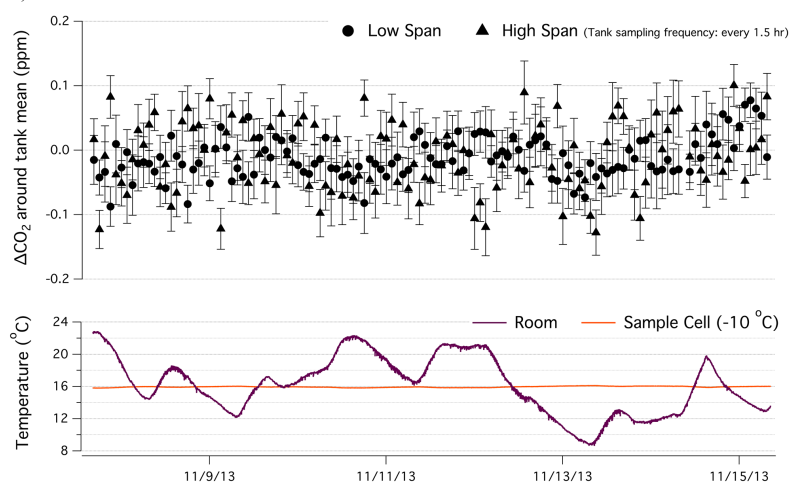

Figure 4. (a) Daily average of working tank pairs and individual surveillance tanks measured by ABC at Harvard Forest between 19 June 2013 and 14 February 2014. Working tank pair (low span in square, and high span in triangle) was measured twice every $3 \mathrm{~h}$ for 2 min each. Each pair (in different colors) lasts for about 1 month. Data are plotted around the mean of all measurements for each tank. Error bars show the 1 standard deviation of all working tank measurements on each day. Data gaps are due to power, purge gas or pump failure. (b) Week-long $\mathrm{ABC}$ working tank measurements at Harvard Forest, during which the room temperature varied $14 \mathrm{~K}$. Each symbol represents one-time tank measurement (not the daily average as shown in a). Data points and error bars show the mean and the standard deviation in the last $30 \mathrm{~s}$ of each 2 min measurement period (sampling rate at $1 \mathrm{~Hz}$ ). Concurrent temperature profiles of the instrument room and the sample cell are also shown for reference (lower panel).

time coverage from the same individual tank. In general, $\mathrm{ABC}$ showed no systematic drifts and the day-to-day $\mathrm{CO}_{2}$ variation was below about $\pm 0.1 \mathrm{ppm}$, which meets the World Meteorological Organization Data Quality Objectives for the Northern Hemisphere (WMO, 1993).

Figure $4 \mathrm{~b}$ shows $\mathrm{ABC}$ 's working tank measurements over a 1-week period which was chosen because the room temperature varied by $14 \mathrm{~K}$. Despite this very large temperature swing, all individual tank measurements (not merely the daily average) were stable within $\pm 0.1 \mathrm{ppm} \mathrm{CO}_{2}$, showing no measurable temperature dependency even at this very high level of measurement precision.

These results demonstrate that $\mathrm{ABC}$ is capable of measuring at remote sites for almost a year (and probably longer) without maintenance or calibration. Its stability of $<0.3 \mathrm{ppm}$ peak to peak over 8 months surpasses or competes with that of any major brand $\mathrm{CO}_{2}$ spectrometer (Andrews et al., 2014; Richardson et al., 2012; Picarro G2301 Analyzer Data Sheet, http://www.picarro.com/ products_solutions/trace_gas_analyzers/co_co2_ch4_h2o).

\subsection{Field performance - ambient sampling}

We compared ABC's ambient air measurements to those of a Cavity Ring-Down Spectrometer (Picarro G2301) sampling at the same height through a different inlet on the same flux tower, and the results show relatively good agreement between the two.

The Picarro instrument has been measuring at the HFEMS since the summer of 2012. It was set up to measure $\mathrm{CO}_{2}, \mathrm{CH}_{4}$, and $\mathrm{H}_{2} \mathrm{O}$ at eight heights on the tower $(0.3,0.8$, $4.5,7.5,12.7,18.3,24.1$ and $29.0 \mathrm{~m}$ ). The reported $\mathrm{CO}_{2}$ from the Picarro G2301 has been corrected for water interference (lab characterization following Rella et al., 2013, and Chen et al., 2010) and for the $\mathrm{CO}_{2}$ response curve (on-site calibration). One reference tank is measured by Picarro every $6 \mathrm{~h}$ to monitor instrument drift. Both the Picarro calibration tanks and the $\mathrm{ABC}$ reference tanks were calibrated against WMO standards at Harvard University, but using different instruments (Picarro and Licor, respectively).

Figure 5 compares $\mathrm{CO}_{2}$ time series from $\mathrm{ABC}$ and the Picarro G2301, for the same height on the tower $(29.0 \mathrm{~m}$, through different inlets) during a week in between 2 and 8 January 2014. The two instruments tracked each other very well. The signals display relatively small daily $\mathrm{CO}_{2}$ variations above the canopy due to low biological activity in winter. The Picarro G2301 measurements have a $\sim 3$ s output interval while $\mathrm{ABC}$ measures at $1 \mathrm{~Hz}$ and can be set even faster $(10 \mathrm{~Hz}$ with $0.09 \mathrm{ppm}$ precision, compared to $0.15 \mathrm{ppm}$ precision at every $5 \mathrm{~s}$ for Picarro G2301). The mean $\mathrm{CO}_{2}$ difference of the two measurements (ABC - Picarro G2301) is $-0.04 \pm 0.22 \mathrm{ppm}$ during this 1 -week period. ABC currently measures Nafion (Perma Pure PD-200T-48) dried air samples but does have the potential for water measurement and correction. Spectral regions with co-existing $\mathrm{CO}_{2}$ and water absorption lines with appropriate line separations and line strengths are available (Xiang, 2013).

\subsection{Field performance - accuracy}

We used two sets of surveillance gas cylinders to test the accuracy of $\mathrm{ABC}$ and characterize its response to the $\mathrm{CO}_{2}$ mixing ratio. One set has five aluminum tanks (Scott Specialty Gases and Scott-Marrin Inc., USA; same as those used for stability test in Sect. 3.2); the other set has three steel tanks 


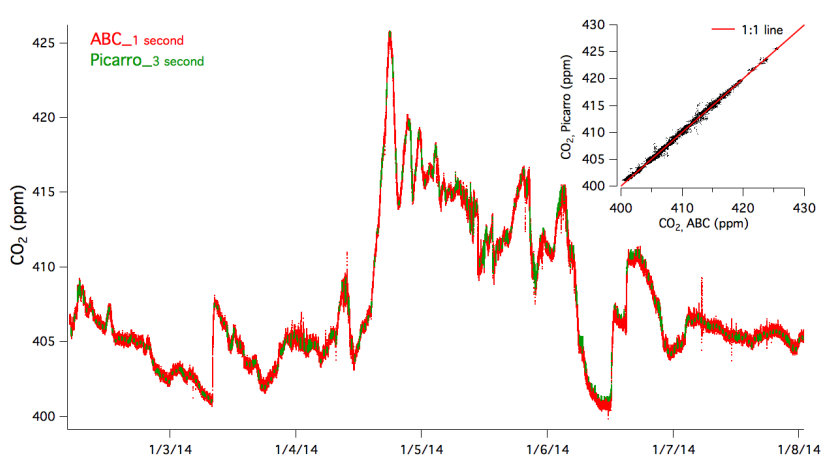

Figure 5. Ambient air measurements from $\mathrm{ABC}$ and Picarro above the canopy in Harvard Forest between 2 and 8 January 2014.

(Airgas Inc., USA) primarily serving as the reference gas cylinders for the $\mathrm{CO}_{2}$-isotope spectrometer. All surveillance tanks were calibrated by a NDIR analyzer (a modified Licor 6251) at Harvard University and were traceable to the WMO Central Calibration Lab (CCL) $\mathrm{CO}_{2}$ standards. We corrected the Licor measured $\mathrm{CO}_{2}$ values for all cylinders according to their isotopic compositions and the Licor relative molar response (Tohjima et al., 2009; Xiang et al., 2013). The mixing ratio and isotopic composition of $\mathrm{CO}_{2}$ in each cylinder are summarized in Table 1.

$\mathrm{ABC}$ responds very linearly to $\mathrm{CO}_{2}$ between 330 and $500 \mathrm{ppm}$, though there is detectible nonlinearity less than $0.2 \mathrm{ppm}$. Figure 6 shows the repeated $\mathrm{ABC}$ measurements of all surveillance tanks between June 2013 and February 2014 without any calibration or correction applied. Linear regression of all aluminum tank measurements (340-460 ppm) has a slope of $0.997,3 \%$ different from unity. The average fit residual for each tank is less than $0.2 \mathrm{ppm}$ different from Licor calibrated values. At this $0.2 \mathrm{ppm} \mathrm{CO}_{2}$ level, it is difficult to accurately attribute the bias sources to instrument uncertainties of $\mathrm{ABC}$ or Licor (e.g., instability, linear response, isotope effects, interferences) and tank drifts (e.g., due to fill gas sources, impurities, usage, leakage, position, tank material, regulator characteristics, ambient temperature, humidity, pressure, and personal operation; Keeling et al., 2007). However, we do observe nonlinearity based on the fit residuals for aluminum tank measurements. According to the null spectral scheme, ABC's accuracy and the stability both deteriorate as the sample $\mathrm{CO}_{2}$ value deviates away from its null point (i.e., the effective $\mathrm{CO}_{2}$ mixing ratio of $\mathrm{ABC}$ 's quartz reference cell) of $385.20 \pm 0.02 \mathrm{ppm}$. This can partly explain the observed nonlinearity.

We did not include steel surveillance tanks in the above discussion because of their observed instabilities with ambient temperature. In a short-term temperature test, clear contrast was observed as we alternately measured a steel (Airgas Inc., USA) and an aluminum $\mathrm{CO}_{2}$ tank (Scott-Marrin Inc., USA). Both experienced a rapid temperature increase from about $4{ }^{\circ} \mathrm{C}$ to room temperature in an hour. During this hour,

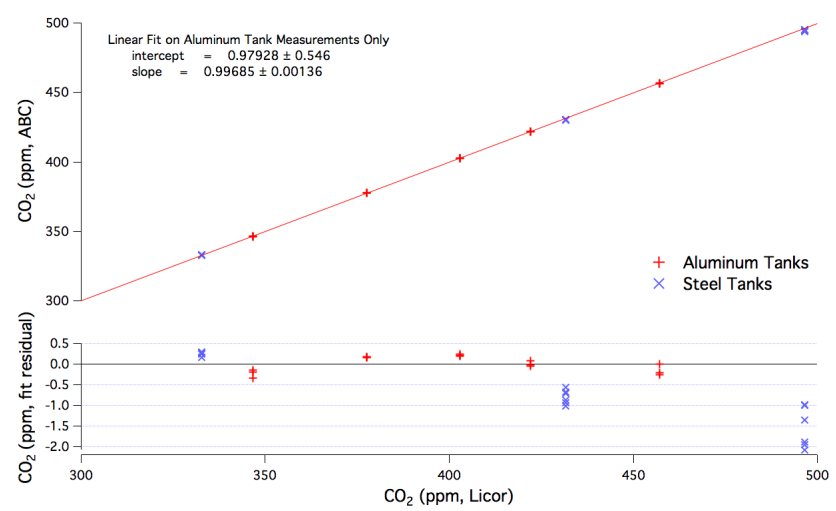

Figure 6. Repeated surveillance tank measurements at Harvard Forest field site between June 2013 and February 2014, showing the general linear response of $\mathrm{ABC}$ to $\mathrm{CO}_{2}$ mixing ratios between 330 and $500 \mathrm{ppm}$. No calibration was performed during this 8 -month period.

$\mathrm{ABC}$ measurements from the steel tank went up by $0.7 \mathrm{ppm}$; meanwhile those for the aluminum tank stayed constant. Over the 8-month field test, repeated $\mathrm{ABC}$ measurements of steel tanks (housed without temperature conditioning) also show tight and positive correlations with ambient temperature: up to $0.13 \mathrm{ppm} \mathrm{CO}_{2}$ variation (delta) and the temperature correlation coefficient $(R)$ is 0.73 for the $332.7 \mathrm{ppm}$ tank; delta $=0.44 \mathrm{ppm}, R=0.91$ for the $431.2 \mathrm{ppm}$ tank; and delta $=1.10 \mathrm{ppm}, R=0.96$ for the $496.4 \mathrm{ppm}$ tank. On the other hand, we did not observe this temperature correlation for the aluminum surveillance tanks (housed in the same room with steel tanks). Surface reactions and gas impurities are likely the causes for this temperature effect on steel tanks. Our results reinforce the recommendation from NOAA ESRL/CCGG (US National Oceanic and Atmospheric Administration Earth System Research Laboratory/Carbon Cycle Greenhouse Gases Group) for the use of aluminum rather than steel gas cylinders as references for high-precision $\mathrm{CO}_{2}$ measurements (Kitzis, 2009).

\section{Summary}

We have developed a spectrometer for measuring absolute $\mathrm{CO}_{2}$ mixing ratios in ambient air and demonstrated its longterm field deployment in this study. The major improvements compared to the lab-based prototype are improved temperature stabilization, and mTorr-level sample cell pressure measurement accuracy. Field measurements showed exceptional instrument stability and accuracy: repeatability to within $0.1 \mathrm{ppm}$ over 8 months without any on-site calibration, and accuracy to within $0.2 \mathrm{ppm}$ compared to Licor calibrated values traceable to the WMO standards. Field comparison with a Picarro $\mathrm{CO}_{2}$ instrument showed good agreement.

The $\mathrm{ABC}$ instrument is designed for long-term continuous monitoring of atmospheric $\mathrm{CO}_{2}$ at remote sites. Its stability 
and accuracy without calibration gas consumption allow for simpler and less expensive operation without loss of reliability. The ABC instrument could also facilitate a global monitoring network with a central calibration lab for characterizing the quartz reference cells, which could be easily shipped to sites for inter-comparison or to serve as long-term stable references. This development work has moreover confirmed the potential of spectroscopic measurements for accurate, long-term, remote monitoring of other stable atmospheric species (and their isotopologues) with minimal reference gas consumption.

Acknowledgements. B. Xiang thanks Elaine Gottlieb and Jasna Vellovic Pittman from Harvard University for calibrating the $\mathrm{CO}_{2}$ calibration tanks used in this study. B. Xiang also thanks Steve Huchro and Lloyd Wright from Solid State Cooling for developing and updating their chiller products. We acknowledge the help from the technical staff at Aerodyne Research Inc. and the Harvard Forest field staff. This work is funded by the DOE SBIR program under grant number DE-5C0000905.

Edited by: F. Stroh

\section{References}

Andersen, P. C., Williford, C. J., David, D. E., and Birks, J. W.: Ultrasonic detector for high precision measurements of carbon dioxide, Anal. Chem., 82, 7929-7934, 2010.

Andrews, A. E., Kofler, J. D., Trudeau, M. E., Williams, J. C., Neff, D. H., Masarie, K. A., Chao, D. Y., Kitzis, D. R., Novelli, P. C., Zhao, C. L., Dlugokencky, E. J., Lang, P. M., Crotwell, M. J., Fischer, M. L., Parker, M. J., Lee, J. T., Baumann, D. D., Desai, A. R., Stanier, C. O., De Wekker, S. F. J., Wolfe, D. E., Munger, J. W., and Tans, P. P.: $\mathrm{CO}_{2}, \mathrm{CO}$, and $\mathrm{CH}_{4}$ measurements from tall towers in the NOAA Earth System Research Laboratory's Global Greenhouse Gas Reference Network: instrumentation, uncertainty analysis, and recommendations for future high-accuracy greenhouse gas monitoring efforts, Atmos. Meas. Tech., 7, 647-687, doi:10.5194/amt-7-647-2014, 2014.

Baer, D. S., Paul, J. B., Gupta, M., and O'Keefe, A.: Sensitive absorption measurements in the near-infrared region using off-axis integrated-cavity-output spectroscopy, Appl. Phys. B, 75, 261265, 2002.

Chen, H., Winderlich, J., Gerbig, C., Hoefer, A., Rella, C. W., Crosson, E. R., Van Pelt, A. D., Steinbach, J., Kolle, O., Beck, V., Daube, B. C., Gottlieb, E. W., Chow, V. Y., and Santoni, G. W.: High-accuracy continuous airborne measurements of greenhouse gases $\left(\mathrm{CO}_{2}\right.$ and $\left.\mathrm{CH}_{4}\right)$ using the cavity ring-down spectroscopy (CRDS) technique, Atmos. Meas. Tech., 3, 375-386, 2010, http://www.atmos-meas-tech.net/3/375/2010/.

Daube, B. C., Boering, K. A., Andrews, A. E., and Wofsy, S. C.: A high-precision fast-response airborne $\mathrm{CO}_{2}$ analyzer for in situ sampling from the surface to the middle stratosphere, J. Atmos. Ocean. Tech., 19, 1532-1543, 2002.

Engeln, R., Berden, G., Peeters, R., and Meijer, G.: Cavity enhanced absorption and cavity enhanced magnetic rotation spectroscopy, Rev. Sci. Instrum., 69, 3763-3769, 1998.
Esler, M. B., Griffith, D. W. T., Wilson, S. R., and Steele, L. P.: Precision trace gas analysis by FT-IR spectroscopy. 1. Simulaaneous analysis of $\mathrm{CO}_{2}, \mathrm{CH}_{4}, \mathrm{~N}_{2} \mathrm{O}$, and $\mathrm{CO}$ in air, Anal. Chem., 72, 206-215, 2000.

Goulden, M. L., Munger, J. W., Fan, S. M., Daube, B. C., and Wofsy, S. C.: Measurements of carbon sequestration by long-term eddy covariance: Methods and a critical evaluation of accuracy, Glob. Change Biol., 2, 169-182, 1996.

Keeling, R. F., Manning, A. C., Paplawsky, W. J., and Cox, A. C.: On the long-term stability of reference gases for atmospheric $\mathrm{O}_{2} / \mathrm{N}_{2}$ and $\mathrm{CO}_{2}$ measurements, Tellus B, 59, 3-14, 2007.

Kitzis, D.: Preparation and stability of standard reference air mixtures, NOAA Earth System Research Laboratory Carbon Cycle Greenhouse Gases group and Cooperative Institute for Research in Environmental Sciences, University of Colorado at Boulder, available at: http://www.esrl.noaa.gov/gmd/ccl/airstandard.html (last access: 12 December 2014), 2009.

McManus, J. B., Zahniser, M. S., Nelson, D. D., Shorter, J. H., Herndon, S., Wood, E., and Wehr, R.: Application of quantum cascade lasers to high-precision atmospheric trace gas measurements, Opt. Eng., 49, 111-124, 2010.

McManus, J. B., Zahniser, M. S., and Nelson, D. D.: Dual quantum cascade laser trace gas instrument with astigmatic Herriott cell at high pass number, Appl. Optics, 50, 74-85, 2011.

Rella, C. W., Chen, H., Andrews, A. E., Filges, A., Gerbig, C., Hatakka, J., Karion, A., Miles, N. L., Richardson, S. J., Steinbacher, M., Sweeney, C., Wastine, B., and Zellweger, C.: High accuracy measurements of dry mole fractions of carbon dioxide and methane in humid air, Atmos. Meas. Tech., 6, 837-860, doi:10.5194/amt-6-837-2013, 2013.

Richardson, S. J., Miles, N. L., Davis, K. J., Crosson, E. R., Rella, C. W., and Andrews, A. E.: Field Testing of Cavity Ring-Down Spectroscopy Analyzers Measuring Carbon Dioxide and Water Vapor, J. Atmos. Ocean. Tech., 29, 397-406, doi:10.1175/JTECH-D-11-00063.1, 2012.

Tans, P., Zhao, C., and Kitzis, D.: The WMO mole fraction scales for $\mathrm{CO}_{2}$ and other greenhouse gases, and uncertainty of the atmospheric measurements, a report prepared for the 15 th WMO/IAEA Meeting of Experts on Carbon Dioxide, Other Greenhouse Gases, and Related Tracer Measurement Techniques, Jena, Germany, available at: http://www.esrl.noaa.gov/ gmd/ccl/co2report.html (last access: 12 December 2014), 2009.

Tohjima, Y., Katsumata, K., Morino, I., Mukai, H., Machida, T., Akama, I., Amari, T., and Tsunogai, U.: Theoretical and experimental evaluation of the isotope effect of NDIR analyzer on atmospheric $\mathrm{CO}_{2}$ measurement, J. Geophys. Res., 114, D13302, doi:10.1029/2009JD011734, 2009.

Tuzson, B., Zeyer, K., Steinbacher, M., McManus, J. B., Nelson, D. D., Zahniser, M. S., and Emmenegger, L.: Selective measurements of $\mathrm{NO}, \mathrm{NO}_{2}$ and $\mathrm{NO}_{\mathrm{y}}$ in the free troposphere using quantum cascade laser spectroscopy, Atmos. Meas. Tech., 6, 927-936, doi:10.5194/amt-6-927-2013, 2013.

Urbanski, S., Barford, C., Wofsy, S., Kucharik, C., Pyle, E., Budney, J., McKain, K., Fitzjarrald, D., Czikowsky, M., and Munger, J. W.: Factors controlling $\mathrm{CO}_{2}$ exchange on timescales from hourly to decadal at Harvard Forest, J. Geophys. Res.-Biogeo., 112, G02020, doi:10.1029/2006JG000293, 2007.

Wehr, R., Munger, J. W., Nelson, D. D., McManus, J. B., Zahniser, M. S., Wofsy, S. C., and Saleska, S. R.: Long-term eddy 
covariance measurements of the isotopic composition of the ecosystem-atmosphere exchange of $\mathrm{CO}_{2}$ in a temperate forest, Agr. Forest Meteorol., 181, 69-84, 2013.

Wofsy, S. C., Goulden, M. L., Munger, J. W., Fan, S. M., Bakwin, P. S., Daube, B. C., Bassow, S. L., and Bazzaz, F. A.: Net exchange of $\mathrm{CO}_{2}$ in a midlatitude forest, Science, 260, 1314-1317, 1993.

World Meteorological Organization (WMO): Global Atmosphere Watch, report of the Seventh WMO Meeting of Experts on Carbon Dioxide Concentration and Isotopic Measurement Techniques, WMO/TD-No. 669, No. 88 Rome, Italy, 1993.
Xiang, B.: Interactive comment on "Towards a stable and absolute atmospheric carbon dioxide instrument using spectroscopic null method", Atmos. Meas. Tech. Discuss., 6, C1039-C1047, 2013.

Xiang, B., Nelson, D. D., McManus, J. B., Zahniser, M. S., and Wofsy, S. C.: Towards a stable and absolute atmospheric carbon dioxide instrument using spectroscopic null method, Atmos. Meas. Tech., 6, 1611-1621, doi:10.5194/amt-6-1611-2013, 2013. 